Dangerous Pleasures 
A

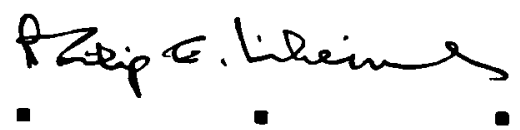

BOOK

The Philip E. Lilienthal imprint honors special books

in commemoration of a man whose work

at the University of:California Press from 1954 to 1979 was marked by dedication to young authors and to high standards in the field of Asian Studies. Friends, family, authors, and foundations have together endowed the Lilienthal Fund, which enables the Press to publish under this imprint selected books in a way that reflects the taste and judgment of a great and beloved editor. 


\section{Dangerous Pleasures}

Prostitution and Modernity in Twentieth-Century Shanghai

\section{Gail Hershatter}




\section{The publisher gratefully acknowledges the generous contribution provided by China Publication Subventions.}

Permission to reprint material published elsewhere has been granted as follows:

"The Hierarchy of Shanghai Prostitution, 1919-1949," Modern China 15.4 (October 1989): 463-97, () 1989 Sage Publications, Inc.

"Prostitution and the Market in Women in Early Twentieth-Century Shanghai," in Rubie S. Watson and Patricia Buckley Ebrey, eds., Marriage and Inequality in Chinese Society. Berkeley, Los Angeles, and Oxford: University of California Press, 1991, 256-85, (C) 1991 by the Regents of the University of California.

"Courtesans and Streetwalkers: The Changing Discourses on Shanghai Prostitution, 1890-1949," Journal of the History of Sexuality 3.2 (October 1992): 245-69, (C) 1992 by The University of Chicago.

"Regulating Sex in Shanghai: The Reform of Prostitution in 1920 and 1951," in Frederic Wakeman, Jr., and Wen-hsin Yeh, eds., Shanghai Sojourners. Berkeley: University of California Institute of East Asian Studies, 1992, 145-85, (C) $199^{2}$ by the Regents of the University of California.

"The Subaltern Talks Back: Reflections on Subaltern Theory and Chinese History," positions: east asia cultures critique 1.1 (spring 1993), 103-30, (c) 1993 by Duke University Press.

"Modernizing Sex, Sexing Modernity: Prostitution in Early Twentieth-Century Shanghai," in Christina Gilmartin, Gail Hershatter, Lisa Rofel, and Tyrene White, eds., Engendering China: Women, Culture, and the State. Cambridge: Harvard University Press, 1994, 147-74, $(1994$ by the President and Fellows of Harvard College.

University of California Press

Berkeley and Los Angeles, California

University of California Press, Ltd.

London, England

$$
\text { (C) } 1997 \text { by }
$$

The Regents of the University of California

Library of Congress Cataloging-in-Publication Data

Hershatter, Gail.

Dangerous pleasures: prostitution and modernity in twentieth-century Shanghai / Gail Hershatter.

p. $\mathrm{cm}$.

"A Philip E. Lilienthal book"-

Includes bibliographic references and index

ISBN 0-520-20438-7. (alk. paper). -ISBN o-520-20439-5(pbk.: alk. paper)

1. Prostitution-China-Shanghai-History-2oth Century. 2. Women-China-

Shanghai-Social Conditions. 3. Women-China-Shanghai-Economic conditions.

4. Shanghai (China)-History-2oth century. 5. Shanghai (China)-Social conditions. I. Title. $\mathrm{HQ}_{125}{ }^{\circ} \mathrm{S}_{52} \mathrm{H}_{47} \quad 1997$

$306.74^{\prime} 095^{1} 132-d c 20$

Printed in the United States of America

$\begin{array}{lllllllll}9 & 8 & 7 & 6 & 5 & 4 & 3 & 2 & 1\end{array}$

The paper used in this publication meets the minimum requirements of American National Standards for Information Sciences-Permanence of Paper for Printed Library Materials,

ANSI Z39.48-1984. 
For Sarah and Zachary 
